\title{
Planning for nodes, places, and people in Flanders and Brussels: An empirical railway station assessment tool for strategic decision-making
}

\author{
Freke Caset \\ Ghent University \\ Vrije Universiteit Brussel \\ freke.caset@ugent.be \\ Ben Derudder \\ Ghent University \\ ben.derudder@ugent.be

\section{Frank Witlox} \\ Ghent University \\ frank.witlox@ugent.be
}

\author{
Filipe Marques Teixeira \\ Ghent University \\ Filipe.MarquesTeixeira@ugent.be
}

\author{
Kobe Boussauw \\ Vrije Universiteit Brussel \\ Kobe.Boussauw@vub.be
}

Abstract: Against the backdrop of current policy discussions in Flanders dealing with urban development schemes for strategic railway stations, this paper develops an empirical railway station assessment tool. We build on the node-place modeling literature, and more specifically on the tradition of empirical station assessment models that has emerged from it. First, we propose a number of methodological contributions in which we aim to improve the analytical strength of some standard node-place parameters, to expand the model with a user-based accessibility account and to broaden the appraisal of a station's accessibility with a temporal component. Second, we apply the conceptual model to Flanders and the Brussels-Capital Region (Belgium). Drawing on factor and cluster analysis, we produce two intelligible station typologies for both the node-place and user-based data. Both typologies are interpreted and complemented with station-specific rose diagrams, summarizing a station's accessibility profile. These diagrams inform about station-specific accessibility characteristics, some of which are not captured by conventional node-place analyses. Lastly, we elaborate on five exemplary cases and illustrate what the results of these analyses may mean for planning practice.

Keywords: Accessibility, railway stations, node-place model, integrated planning, planning support tool, Flanders

\section{Article history:}

Received: November 6, 2018

Received in revised form:

March 18, 2019

Accepted: September 8, 2019

Available online: November 7 , 2019

Copyright 2019 Freke Caset, Filipe Marques Teixeira, Ben Derudder, Kobe Boussauw, \& Frank Witlox http://dx.doi.org/10.5198/jtlu.2019.1483

ISSN: 1938-7849 | Licensed under the Creative Commons Attribution - Noncommercial License 4.0

The Journal of Transport and Land Use is the official journal of the World Society for Transport and Land Use (WSTLUR) and is published and sponsored by the University of Minnesota Center for Transportation Studies. 


\section{$1 \quad$ Introduction}

\subsection{Flanders in 2050: an ambitious spatial development program organized around strategic railway nodes}

"In 2050, every citizen of Flanders can travel easily each day. We will have organized our space in such a way that the need to travel around is reduced. More Flemish citizens can travel in a sustainable manner. They will take the bicycle or train to commute and leave the car in the garage more often."

Flemish Government (2017, p. 23, own translation)

The regional government of Flanders (the northern, Dutch-speaking part of Belgium) has recently engaged itself to develop a "metropolis Flanders," an urbanized region that "ought to be large and efficient enough to position itself successfully in the urban economic network of the north-western European delta" (Boussauw et al., 2018, p. 8). It is clear that high levels of both external and internal connectivity are paramount for meeting this objective. The region nonetheless experiences a variety of related pressures that may impede achieving this objective, including heavy road congestion, air pollution and landscape fragmentation. All of these pressures are strongly associated with Flanders' highly peri-urbanized and suburbanized spatial structure. Today, this diffuse urbanity (see Figure 1) hinges on, and is mutually enhanced by, a mobility system that is dominated by car use and ownership (Blondia, 2014; Fransen et al., 2015). Although enhancing collective transport is often proposed as an important solution to the mobility problem, land use and public transport developments are rarely successfully integrated in Flanders. A major reason for this is that the critical mass to organize a well-functioning public transport system is missing in most locations given a "nebular" settlement morphology (Blondia \& De Deyn, 2012). Furthermore, policy levers in the policy realms of spatial planning and mobility are fragmented across various political-administrative levels, often hindering effective integration and coordination (De Vos \& Witlox, 2013; Boussauw \& Boelens, 2015).

Against this backdrop, the Flemish Government recently put forward an ambitious outlook on the future development of the built (and unbuilt) environment in Flanders by 2050 in the preparatory documents for the new Flemish Spatial Policy Plan ("Beleidsplan Ruimte Vlaanderen," hereafter BRV). In 2012, a BRV Green Paper was released, followed by a BRV White Paper in November 2016. Twenty years after the approval of the first comprehensive Spatial Structure plan for Flanders, these policy papers put forward a renewed mid- to long-term vision extending most of the earlier spatial planning principles, albeit with a more strongly pronounced focus on railway-based accessibility as the backbone for future spatial developments. This strategic vision was recently approved by the Flemish Government (2018) and is being translated in a series of operational frameworks for implementation, of which one bears specific relevance in the context of this research: the "spatial backbone" policy paper. ${ }^{1}$

A central objective of this policy paper is to designate strategic public transport nodes which have the highest potential for the allocation of additional urban development. This potential is determined by (1) the extent to which a location is accessible by public transport, and (2) the extent to which jobs, residents and amenities are present. Both criteria have recently been operationalized and mapped for Flanders and Brussels by Verachtert et al. (2016). Drawing on this study, the policy paper puts forward a conceptual typology of railway stations, discerning four types: international nodes, metropolitan nodes, urban-regional nodes, and rural-regional nodes. The first two types of nodes are defined based on a strict lower threshold with respect to both criteria, and unsurprisingly include the largest railway stations of the central and very urbanized area of Flanders alongside the equally urbanized corridors in the directions of Bruges and the Kortrijk-Lille and Maastricht-Aachen-Hasselt-Liège conurbations. Referring to

\footnotetext{
${ }^{1}$ We draw on the draft version of this framework (June 2017).
} 
van Meeteren et al. (2015), the policy paper argues that these "strategic metropolitan regions" constitute a coherent metropolitan labor and consumer market with a strong presence of internationally competitive knowledge-oriented economic activities. The railway network connecting these international and metropolitan nodes is coined the "metropolitan transport system" (MTS, see Figure 1). Drawing on a flanking policy goal of increasing agglomeration economies in the Flemish polycentric region, the MTS network is put forward as Flanders' spatial backbone for future economic development. It is furthermore stated that additional strategic railway nodes and growth areas should be identified along these MTS corridors, both in urban and rural areas, which translates into the two other railway station types mentioned: urban-regional and rural-regional nodes. While the policy documents clearly lay out thoughtful and detailed efforts for defining and selecting the international and metropolitan nodes, the interpretation of the two other types of strategic nodes remains opaque. This is because the exact definition and operationalization is outsourced to the urban-regional governance level. The consultative bodies operating on this smaller scale are expected to select these additional strategic nodes by stimulating cooperation between representatives of the municipalities, the public transport operators, the Flemish Government, and other parties involved.

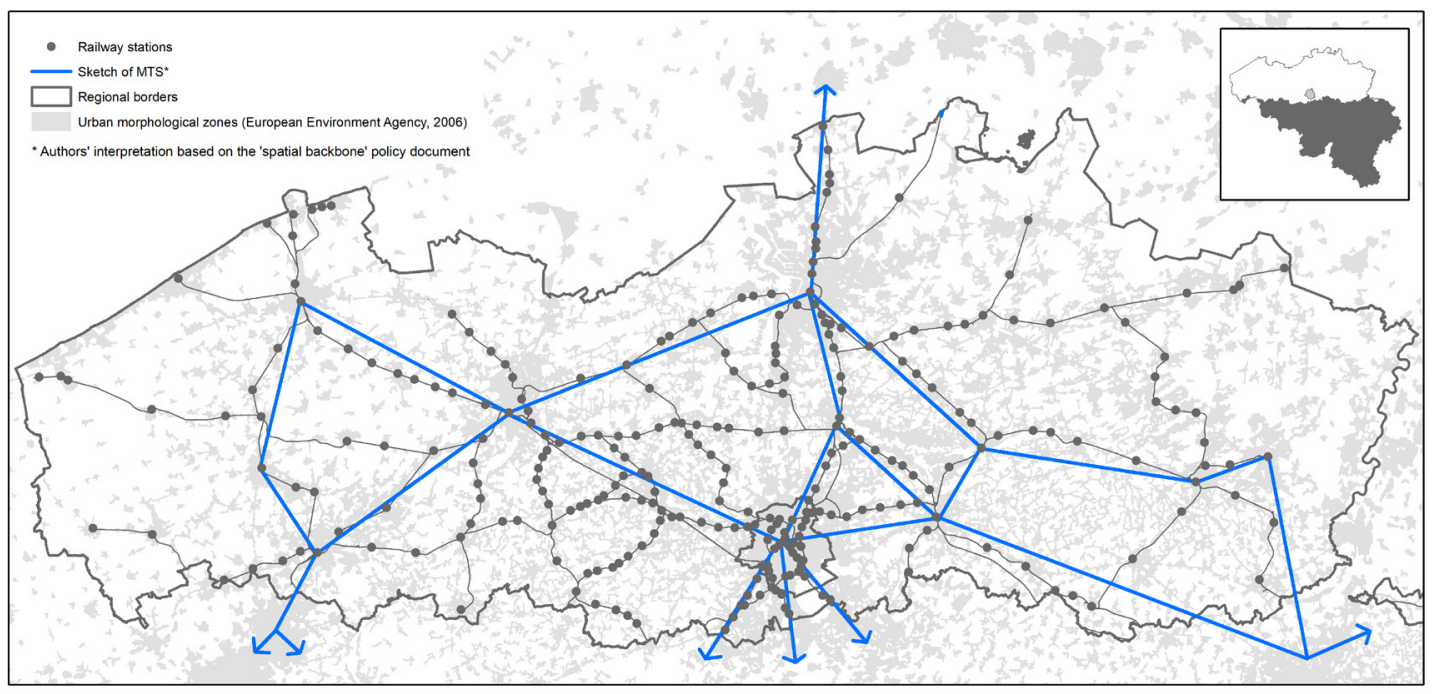

Figure 1. Flanders, its urban morphology and railway network

\subsection{Strategies for stations: Empirical assessment models}

Against the backdrop of this quest to identify strategic railway stations and their differentiated development opportunities, the objective of this paper is to conceptualize, operationalize and analyze a more comprehensive set of empirical parameters that may prove relevant when developing railway station typologies on the regional scale. This objective resonates with the literature on "node-place" modeling (Bertolini \& Spit, 1998; Zweedijk \& Serlie, 1998; Bertolini, 1999). In its most basic guise, the nodeplace model is an analytical framework in which a railway station (area) is operationalized as both a "node" within transport networks and as a "place" within settlement structures. The model allows to describe the relationship between both characteristics for groups of stations in a network and allows to classify these stations into empirically informed typologies (Peek, 2006; Chorus \& Bertolini, 2011).

During the last two decades, the node-place model has been extensively applied and modified in different geographical contexts, both within academic and consultancy contexts. These models range 
from empirical node-place analyses and station typologies to conceptual models in which the underlying mechanisms of node-place interactions are examined by means of, for example, actor analysis (see Peek, 2006, for a series of examples in the Dutch context). Of particular interest here are the type of empirical assessment models which serve the dual purpose of generating station typologies and visualizing the performance of stations on the different node and place criteria in order to allow visual comparisons between stations. These visualizations generally take the shape of polar graphs in which the performance of stations for a set of criteria is plotted along scaled axes with a common origin. Figure 2 provides a (non-exhaustive) overview of these type of node-place models, some of which include additional assessment criteria besides the standard node and place characteristics. The "kite model" (Stadsregio Arnhem Nijmegen, 2011), for example, includes a dimension combining transit ridership and the presence of services at the station (waiting rooms, shops, etc.). In a similar vein, the "node-place-experience" model (Groenendijk, Rezaei, \& Homem de Almeida Correia, 2018) adds indicators reflecting the traveler's experience at the station in terms of comfort (Wi-Fi, sheltered waiting etc.), ambient elements (type of architecture), and personnel presence. Vale, Viana, and Pereira (2018) on the other hand extend the model with a "design" dimension, in line with the commonly cited 3D's (Cervero \& Kockelman, 1997) within transit-oriented development literature. "Design" here refers to the walkability of the built environment in the station area. The web diagram introduced by Singh, Fard, Zuidgeest, Brussel, and van Maarseveen (2018) also measures walkability and bikeability of the station area, along with other extra dimensions such as "user-friendliness" of the station (in terms of, e.g., presence of information displays) and the "passenger load" or capacity utilization of the transit system. And finally, the "butterfly model" (Province of North Holland Noord-Holland and Deltametropool Association, 2013) adds a "proximity" dimension, reflecting the distance of the station to the nearest urbanized settlement.

Depending on the context in which these models were developed and applied, the way in which the models are conceptualized and operationalized varies (Peek, 2006). However, irrespective of the exact criteria included, the shared objective of these assessment models remains to empirically inform policy discussions dealing with the identification of differentiated development opportunities for railway stations from a regional perspective.

\subsection{Research objectives}

The research presented here has a double objective. First, there is a methodological objective in that we further develop this strand of research by paying attention to three main considerations which will be further elaborated in section 2.1: i) improving the analytical strength of some conventional node and place indicators; ii) incorporating information about the people who make use of the station, which reflects the actual demand for accessibility to and from each railway station; and iii) including temporal variations in public transport accessibility in the model. In addition to these methodological refinements to the literature, there is also, second, an empirical and related policy-support objective in that we apply the model to the case of Flanders and Brussels, and this in the broad spirit of the approved BRV strategic vision detailed above.

The remainder of this paper is structured as follows. The specific research objectives are described in section two, and this along with a detailed account of our methodology. Section three then reports on the main findings, while the fourth section deepens our insights into the practical relevance of the results by discussing a selection of exemplary cases. The conclusion reviews our major findings and reflects on avenues for further research. 


\section{Node-place model}

(Bertolini 1999)

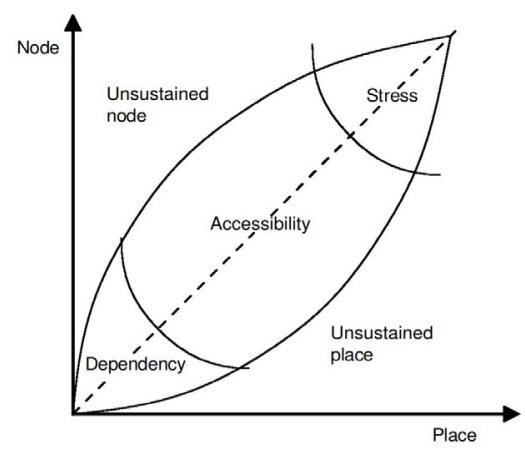

Node-place diagram after Atelier Zuidvleugel (2006)

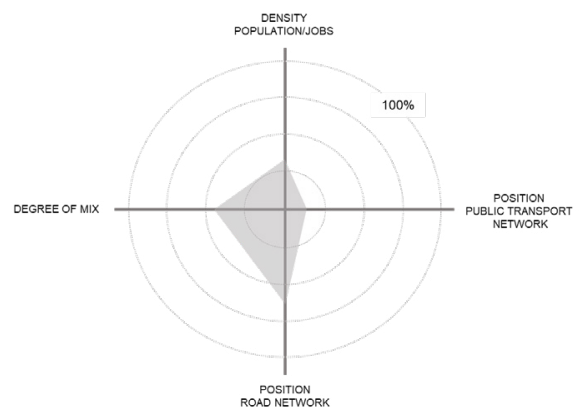

Extended node-place model after Vale et al. (2018)

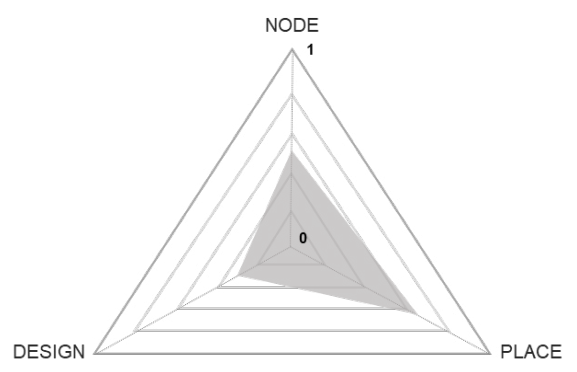

Kite model after Stadsregio Arnhem Nijmegen (2011)

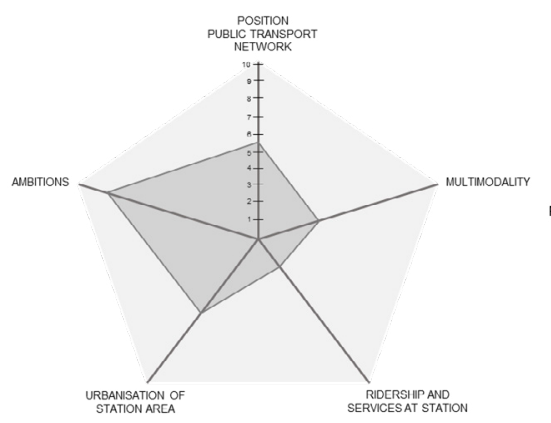

Web diagram after Singh et al. (2018)

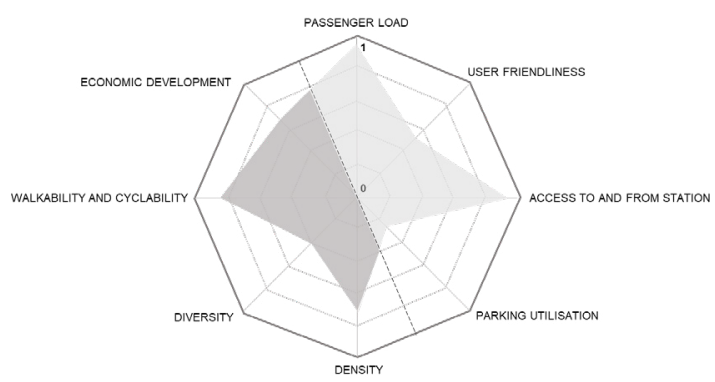

Butterfly model after Provincie Noord-Holland and Vereniging Deltametropool (2013)

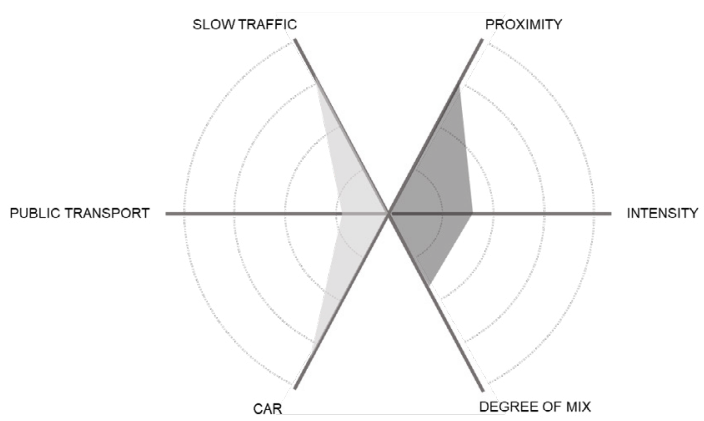

Node-Place-experience model after Groenendijk et al. (2018)

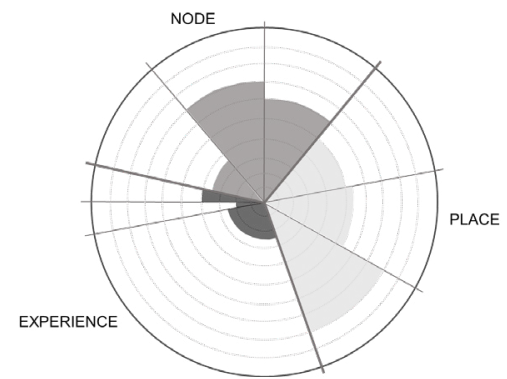

Figure 2. Overview of empirical station assessment models 


\section{$2 \quad$ Methodology}

\subsection{A modified station assessment model for Flanders and Brussels}

In light of the policy-support objective of this paper, an assessment model for the case of railway stations in Flanders and Brussels requires a focus on node and place characteristics. Site-specific indicators regarding facilities or user experiences (presence of kiosks, sheltered waiting and the like) are deemed less relevant in the context of this research. In this way, the "butterfly model" developed and operationalized for all railway stations in the Dutch Province of North Holland offers a good starting point. This model was recently also modified and applied to the case of the Brussels Regional Express Network by Caset, Vale, and Viana (2018). The original butterfly model is composed of two "wings": a node wing (on the left hand side), quantifying the accessibility of the station by bike, public transport and car; and a place wing (on the right hand side), quantifying the proximity of the station to the urban core, the number of inhabitants, jobs and visitors of nearby attractions and the functional mix of jobs and inhabitants. The model qualifies as a location-based accessibility instrument because it quantifies accessibility characteristics of a location (Geurs, 2006). The node and place characteristics included in the model furthermore capture two of the accessibility components discerned by Geurs (2006): the transport and land-use components.

However, Giannopoulous and Boulougaris (1989) among others contend that the notion of accessibility to and from railway stations extends well beyond these supply-side characteristics, since the accessibility of railway stations is also related to temporal constraints and individual needs and capabilities of its users. In Geurs' (2006) framework, temporal constraints relate to differences in travel time and cost depending on time of the day or day of the week, whereas the individual component accounts for stratifications of the population under scrutiny (such as age or income groups). In the case of railway stations, the temporal component mainly relates to the transport component (temporal variations in public or other transport services). The individual component however requires new information to be added to the empirical assessment models discussed above. It requires relevant user- or demand-specific information which may improve particular insights about a station's functioning in the railway network. As a corollary, including all four accessibility components may render a more comprehensive and diversified account of a station's level of accessibility, both from the perspective of the node and the place dimension, but also from the perspective of its users.

The assessment model that resulted from these considerations takes the shape of a rose diagram (see Figure 3). Below, the structure of the diagram is explained, after which the operationalization of the dimensions and indicators is detailed. In the process, we will also discuss where we aim to improve the analytical strength of certain indicators.
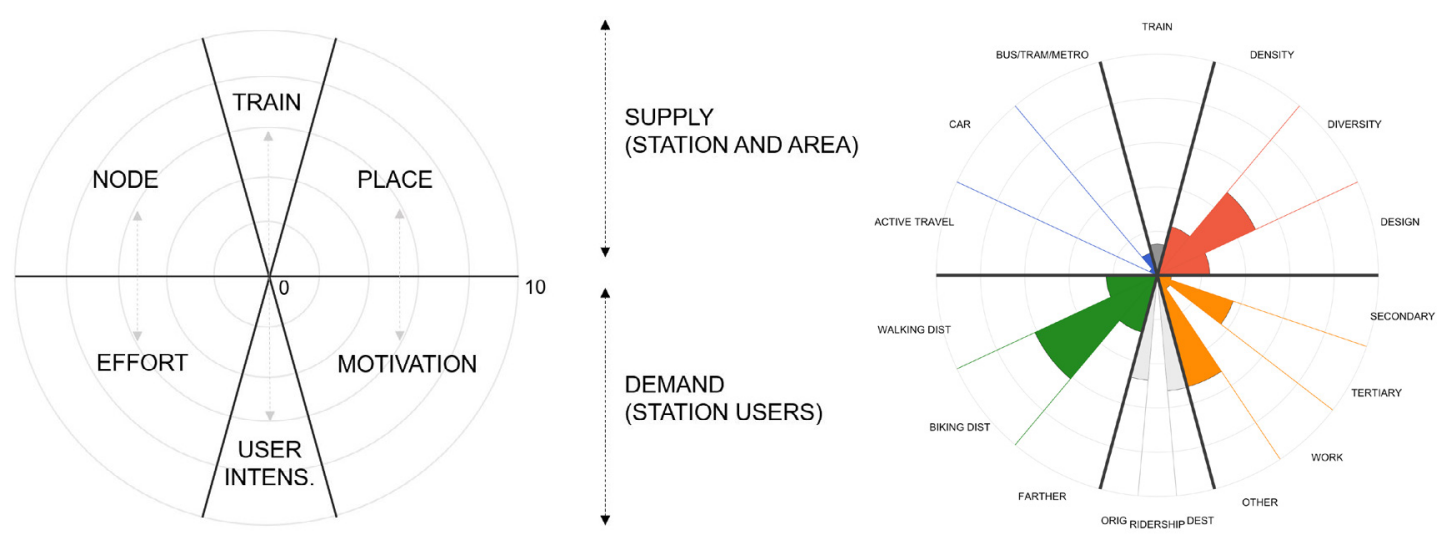

Figure 3. A station area assessment model for Flanders and Brussels: overall structure (left) and dimensions (right) 
The lower part of Figure 3 presents a demand-side perspective to each station's accessibility by visualizing information about the users of a station. Three fields are discerned: effort, ridership and motivation. The first field captures how far people live from the station they use as their origin station, and therefore relates to the effort it takes for people to reach their station of origin. This field relates to the node field in that opportunities to reach a particular station by car or by public transport (reflected in the node dimensions) arguably are more important when most people live far away from their origin station, while for example the bike parking capacity of a station is likely to be more instrumental when most people live within a walkable or bikeable radius from the station. The second field, ridership, reflects the frequency of passengers boarding on a regular working day (the actual ridership) and the extent to which the station functions as an origin or a destination station. Just as with the relation between the effort and node fields, the performance on the ridership field may be matched against that of its opposed train field (confronting supply with demand). In a similar vein, the last field, motivation, relates to the place field, as it depicts the different motives (education, work or other) of the people who employ a particular station as their destination station.

Each indicator is unity-based normalized to vary between 0 and 10 . Then, for each dimension, a multi-criteria analysis is conducted in which all normalized indicator scores are summarized and again normalized per dimension. The visualized scale thus always varies between 0 and 10 , and there will always be at least one station scoring 0 and another scoring 10 for a certain dimension or indicator. A descriptive code is given to each indicator detailing its field ( $\mathrm{N}$ for node, including the train indicators, P for place, and PP for people), followed by its dimension (CA for car, AT for active travel etc.) and an indicator code (freq for frequency etc.), along with the percentage of missing values (MV). Calculations are done for all railway stations (287) with a weekday service in Flanders and Brussels.

\subsection{Operationalization}

\subsubsection{Node dimension}

Table 1. Indicators of the node dimension

\begin{tabular}{|c|c|c|c|}
\hline Code & Indicator description & Source (year) & MV (\%) \\
\hline \multicolumn{4}{|c|}{ ACTIVE TRAVEL } \\
\hline N_AT_park_f & Number of free bike parking places & \multirow[t]{2}{*}{ NMBS (2018) } & 0 \\
\hline N_AT_park_p & Number of paying bike parking places & & 0 \\
\hline \multicolumn{4}{|l|}{$C A R$} \\
\hline N_CA_park_f & Number of free car parking places & \multirow[t]{2}{*}{ NMBS (2018) } & 4 \\
\hline N_CA_park_p & Number of paying car parking places & & 4 \\
\hline \multicolumn{4}{|c|}{ BUS/TRAM/METRO } \\
\hline N_BTM_freq & Frequency of $\mathrm{B} / \mathrm{T} / \mathrm{M}$ departures on a day-basis & \multirow{2}{*}{$\begin{array}{l}\text { Based on GTFS data by De Lijn, } \\
\text { TEC and MIVB/STIB (June } \\
\text { 2018) }\end{array}$} & 0 \\
\hline N_BTM_rout & $\begin{array}{l}\text { Number of unique } \mathrm{B} / \mathrm{T} / \mathrm{M} \text { routes to and from the station } \\
\text { on a day-basis }\end{array}$ & & 0 \\
\hline
\end{tabular}

Both the active travel and the car dimensions focus on the parking capacity for these feeder modes, discerning between free and paying parking services. In order to calculate the accessibility to and from the railway station by public transport, the stops considered very close to the station (within a $300 \mathrm{~m}$ walkable network distance from all possible station exits) were filtered from publicly available GTFS (Gen- 
eral Transit Feed Specification) data using R statistical programming and R studio. For these selected bus, tram and metro stops, two indicators were measured and afterwards grouped (summarized) per railway station, resulting in the indicators listed in Table 1. By drawing on frequently updated GTFS data, this method allows to easily update and calculate these indicators for different time windows. In this research, a typical Tuesday is selected for the calculation of the $\mathrm{B} / \mathrm{T} / \mathrm{M}$ (Bus/Tram/Metro) indicators.

Table 2. Indicators of the train dimension

\begin{tabular}{|c|c|c|c|}
\hline Code & Indicator description & Source (year) & MV (\%) \\
\hline \multicolumn{4}{|l|}{ TRAIN } \\
\hline N_TR_freq_tue & Frequency of departures on a day-basis on Tuesdays & \multirow{6}{*}{$\begin{array}{l}\text { Based on } \\
\text { GTFS data by } \\
\text { NMBS (June } \\
2018 \text { ) }\end{array}$} & 0 \\
\hline N_TR_freq_sat & Frequency of departures on a day-basis on Saturdays & & 0 \\
\hline N_TR_freq_off & Frequency of departures off-peak (between 10 and 11 AM, Tuesdays) & & 0 \\
\hline N_TR_amp & Amplitude between the earliest departure/arrival and latest departure/arrival (Tuesday) & & 0 \\
\hline N_TR_ttcentr & Travel time centrality & & 0 \\
\hline N_TR_trcentr & Transfer centrality & & 0 \\
\hline
\end{tabular}

\subsubsection{Train dimension}

The first four indicators (Table 2) analyze characteristics of the railway service at the station (as is usually done in node-place analyses). However, over the last decade, more advanced accessibility indicators for public transport networks have been developed which assess the position (or "centrality") of a station from a network perspective.

Different methods exist to calculate these types of "network measures" (Curtis \& Scheurer, 2010). Some scholars (e.g., Papa, Moccia, Angiello, \& Inglese, 2013; Caset et al., 2018) employed the open source Urban Network Analysis toolbox for ArcGIS (see Sevtsuk \& Mekonnen, 2012) to calculate these measures, whereas Curtis and Scheurer $(2010,2016)$ developed a series of multimodal public transport centrality measures as part of the SNAMUTS decision tool. As some of these latter measures were previously operationalized for the Flemish and Brussels railway network (see Verachtert et al., 2016), we opted to take the same approach. We operationalized the SNAMUTS "closeness centrality" (equation 1) and "degree centrality" (equation 2) measures (see Curtis \& Scheurer 2016, p. 304). Centrality was measured relative to all Belgian stations and the foreign stations included in the GTFS dataset (those on the railway lines towards Lille, Amsterdam, Maastricht, Aachen, and Luxembourg). In order to enhance the interpretation of the indicators for the users of the tool (and to avoid possible confusion with the standard language used in classic network analysis (see Newman, 2010), we renamed the indicators into "travel time centrality" and "transfer centrality," respectively.

The travel time centrality indicator calculates the minimum cumulative impediment (Lmin, ij) between station $\mathrm{i}$ and all other stations $\mathrm{j}$ in the network (with $\mathrm{N}=$ all railway stations), in terms of travel time $(\mathrm{t})$ and service frequency $(\mathrm{f})$ :

$$
\text { travel time centrality }{ }_{i}=\sum_{j=1, j \neq i}^{N} \frac{L_{\min , i j}}{N-1}
$$

with: impediment value of route segment between stations $i$ and $\mathrm{j}=4 x \sqrt{\frac{t_{i j}}{f_{i j}}}$

The transfer centrality indicator calculates centrality for a station $\mathrm{i}$ in terms of the average minimum number of transfers $(p)$ required to reach all other stations $j$ in the network: 
transfer centrality ${ }_{i}=\sum_{j=1, j \neq i}^{N} \frac{p_{\text {min }, i j}}{N-1}$

Similar to the B/T/M indicators, drawing on GTFS data allows to easily update and calculate these indicators for different time windows. Again, Tuesday is selected for the calculation of these indicators.

In order to calculate the place dimensions, the extent of "the place" needs to be defined. As pointed out by Bertolini and Spit (1998, p. 12), "any delimitation of the station as place is destined to be somewhat arbitrary," as the influence of a station may go far beyond its immediate surroundings. Conversely, entities located nearby may have no apparent relationship with the station. As this paper draws on empirical assessment models which focus on the walkable area of stations, we delineate "place" as the accessible area covered by a walkable street network distance of 1200 meter (roughly 15 minutes walking). Table 3 illustrates the indicators that are part of the place dimensions.

First, the "Density" dimension refers to the concentration of jobs, residents and amenities. Its contribution to the walkability of a transit-oriented neighborhood is detailed in Cervero and Kockelman (1997). The rationale is that density provides the potential to reduce distances between people and the places they need to access. There are a variety of analytical approaches to measure density (for a recent overview see Dovey \& Pafka, 2018a). Here we adopt the most commonly used measures of population density (residents/hectare and jobs/hectare) along with three measures reflecting the density of amenities (basic amenities/hectare, regional amenities/hectare and metropolitan amenities/hectare). The difference between the three types of amenities is specified in Verachtert et al. (2016). In general terms, basic amenities are those considered necessary to organize daily life (e.g., a kindergarten, a pharmacy, a general practitioner). Regional amenities are assumed to have a larger catchment, serving different urban areas in the region (e.g., a shopping mall, a cultural center, offices), while metropolitan amenities have the largest catchment (e.g., touristic attractions, a university). Based on the coordinates of the individual amenity locations, distance decay functions were applied (depending on the assumed amenity catchment size) and rescaled to a raster with $100 \mathrm{~m}$ x $100 \mathrm{~m}$ cells.

Second, "Diversity" or land-use mix is a key ingredient of walkability (Dovey \& Pafka, 2018b). In the node-place modeling literature, this dimension is often operationalized by employing the entropy measure used by Zweedijk and Serlie (1998), the dissimilarity index introduced by Cervero and Kockelman (1997), the MXI (Mixed-use Index) proposed by van den Hoek (2008), or other types of functional mix measures (such as the "Mixed-ness Index" applied by Singh, Luckman, Flacke, Zuidgeest, \& van Maarseveen, 2017). While these measures capture "functional" land-use mix, they do not capture the spatial configuration of the land-use types (a critique that was already raised by Hess, Moudon, \&, Logsdon, 2001). Given this, we draw on the work of Hess et al. (2001) in which a landscape ecology approach to measuring "patch" diversity is applied within the context of transport and land use interaction studies. Using the Fragstats software (see McGarigal \& Marks, 1995), two indicators are measured, which reflect the functional and the spatial diversity of land-use types within each station's precinct: the Shannon's Diversity Index (SHDI, equation 3) and the Contagion Index (CI, equation 4).

$$
S H D I=-\sum_{i=1}^{m}\left(P_{i} \cdot \ln P_{i}\right)
$$

with: i the type of land use and Pi the proportion of land-use type i present within the station's precinct. SHDI increases as the number of different land-use types increases and/or the proportional distribution of area among types becomes more equitable. 
CI measures both the land-use "interspersion" (the spatial intermixing of raster cells with different types of land use) and its "dispersion" (the spatial distribution of a land-use type with respect to the station precinct), at the level of individual raster cells. Higher CI values may point to precincts with a few large and contiguous land-use patches, whereas lower values generally characterize precincts with many small and dispersed land-use patches. CI, detailed mathematically below, represents the observed level of contagion as a percentage of the maximum, given the total number of land-use types:

$$
C I=1+\frac{\sum_{i=1}^{m} \sum_{k=1}^{m}\left[P_{i} \frac{g_{i k}}{\sum_{k=1}^{m} g_{i k}} \cdot \ln \left(P_{i}\right) \frac{g_{i k}}{\sum_{k=1}^{m} g_{i k}}\right]}{2 \ln (m)} \cdot 100
$$

More specifically, CI consists of the sum, over land-use types, of the product of two probabilities: the probability that a random chosen raster cell belongs to type $\mathrm{i}$ (estimated by the proportional abundance of type i), and the conditional probability that given a cell is of type $i$, one of its neighboring cells belongs to type $j$ (estimated by the proportional abundance of type $i$ adjacencies involving type $j$ ) (see McGarigal \& Marks, 1995). Equally crucial here is the way in which the land-use types, functioning as proxies for walking trip origins and destinations, are defined. The approach to land-use categorization adopted here draws on the triangular model of functional mix in which urban functions are divided into just three primary categories of housing, work and amenities (see van den Hoek, 2008; Nes, Berghauser, \& Mashhoodi, 2012; Dovey \& Pafka, 2018b). We draw on land-use data on a 10-meter raster scale containing 39 land-use types, which we assigned to the three categories.

The third "D," design, is added to the station assessment model. This design dimension aims to measure the ways in which walkable and bikeable access (or "active accessibility," see Vale, Saraiva, \& Pereira, 2016) is mediated by the urban morphology of public space and by the built environment. As regards walkable access, in line with Pafka and Dovey (2018), two key approaches are applied, i.e. walkable catchments and permeability. The first indicator measures the "catchment" of a station, not in terms of its walkable surface (or "Pedshed," which is frequently used in node-place modelling studies), but in terms of "how much" it gives access to. In line with Pafka and Dovey (2018), we focus on the extent of public/private interface within the station's walkable precinct as a proxy measure for how much is actually "caught." More specifically, this "interface catchment" (IC) is calculated by summarizing the length of all walkable street segments (the public realm) that are also flanked by buildings (the private realm). The second indicator, permeability, measures the extent to which the urban morphology is permeated by publicly accessible space (see also Marshall, 2005) by means of mapping the total number of street crossings per station area (see also Ryan \& Frank, 2009). This measure relates to the ease of movement through an urban area as well as the multiplicity of route choices between any pair of points. Both indicators are complemented by a third one mapping the walkable and bikeable street networks within a station's precinct. 
Table 3. Indicators of the place dimension

\begin{tabular}{|c|c|c|c|}
\hline Code & Indicator description & Source (year) & MV (\%) \\
\hline \multicolumn{4}{|l|}{ DENSITY } \\
\hline P_DE_res & Summarized residential densities for all raster cells in the station's precinct & \multirow[t]{5}{*}{ VITO (see Verachtert et al. 2016) } & 0 \\
\hline P_DE_job & Summarized job densities for all raster cells in the station's precinct & & 0 \\
\hline P_DE_bas & Summarized basic amenity densities for all raster cells in the station's precinct & & 0 \\
\hline P_DE_reg & Summarized regional amenity densities for all raster cells in the station's precinct & & 0 \\
\hline P_DE_met & Summarized metropolitan amenity densities for all raster cells in the station's precinct & & 0 \\
\hline \multicolumn{4}{|l|}{ DIVERSITY } \\
\hline P_DI_shan & Shannon Diversity Index for all raster cells in the station's precinct & \multirow[t]{2}{*}{ Based on VITO (2013) } & 0 \\
\hline P_DI_CI & Contagion Index for all raster cells in the station's precinct & & 0 \\
\hline \multicolumn{4}{|l|}{$D E S I G N$} \\
\hline P_DG_IC & Interface catchment: total length of street segments flanked by buildings & \multirow[t]{2}{*}{ Based on OSM (2018) } & 0 \\
\hline P_DG_perm & $\begin{array}{l}\text { Permeability defined as the ratio of the number of street segments and street intersec- } \\
\text { tions within the CA }\end{array}$ & & 0 \\
\hline P_DG_netw & Network length of walkable and bikeable street infrastructure in station precinct & $\begin{array}{l}\text { Based on OSM (2018) and } \\
\text { Verachtert et al. (2016) }\end{array}$ & 0 \\
\hline
\end{tabular}

\subsubsection{Motivation, ridership and effort dimensions}

The data for these three dimensions was provided by the Belgian national railway company NMBS and is based on a comprehensive analysis of origin-destination season ticket pairs. As for the effort field, NMBS calculated the percentage of people living within a certain Euclidean distance from their origin station: walking distance (closer than $900 \mathrm{~m}$ ), biking distance (between 900 and $3000 \mathrm{~m}$ ) and a farther distance $(>3000 \mathrm{~m})$. The second field, ridership, is structured around three dimensions: origin (the estimated percentage of people using the station as their origin station), ridership (the frequency of passengers boarding trains on a regular working day), and destination (the estimated percentage of people using the station as destination station). We emphasize that both origin and destination do not reflect quantities of travelers (ridership) but specify the proportion of tickets for which the station functions as an origin or a destination station. Thirdly, the motivation field informs us about the (assumed) motivation of people traveling to a particular station. Four categories (dimensions) were discerned: secondary education, tertiary education, work and other. The first three dimensions draw on season ticket data and were categorized by NMBS based on age groups (respectively $<19$ years old, [19 -25$]$ and $>25$ ). The latter dimension "other" reflects individual ticket sale figures. 
Table 4. Indicators of the motivation, ridership and effort fields

\begin{tabular}{|c|c|c|c|}
\hline Code & Indicator description & Source (year) & MV (\%) \\
\hline \multicolumn{4}{|l|}{ MOTIVATION } \\
\hline PP_MOT_sec & $\begin{array}{l}\% \text { of people using the station as destination station for secondary education } \\
\text { purposes }\end{array}$ & \multirow[t]{4}{*}{ NMBS (2018) } & 20 \\
\hline PP_MOT_tert & $\begin{array}{l}\% \text { of people using the station as destination station for tertiary education } \\
\text { purposes }\end{array}$ & & 20 \\
\hline PP_MOT_work & $\%$ of people using the station as destination station for work purposes & & 20 \\
\hline PP_MOT_other & $\%$ of people using the station as destination station for other purposes & & 20 \\
\hline \multicolumn{4}{|l|}{ RIDERHIP } \\
\hline PP_RID_orig & $\%$ of people using the station as an origin station & \multirow{3}{*}{$\begin{array}{l}\text { NMBS }(2017 \\
\text { and 2018) }\end{array}$} & 0 \\
\hline PP_RID_rid & The frequency of passengers boarding trains on a working day & & 0 \\
\hline PP_RID_dest & $\%$ of people using the station as a destination station & & 0 \\
\hline \multicolumn{4}{|l|}{ EFFORT } \\
\hline PP_EFF_walk & $\begin{array}{l}\% \text { of people using the station as origin station who live within a Euclidean } \\
\text { walking distance }(<900 \mathrm{~m})\end{array}$ & \multirow[t]{3}{*}{ NMBS (2018) } & 21 \\
\hline PP_EFF_bike & $\begin{array}{l}\% \text { of people using the station as origin station who live within a Euclidean } \\
\text { biking distance }(900-3000 \mathrm{~m})\end{array}$ & & 21 \\
\hline PP_EFF_far & $\%$ of people using the station as origin station who live farther $(>3000 \mathrm{~m})$ & & 21 \\
\hline
\end{tabular}

\subsection{Analyzing patterns and developing a typology of stations}

Taken together, our model consists of 32 indicators. Most indicators have no missing values, except for those of the motivation (20\%) and effort (21\%) fields. This is due to the existence of tariff zones, ${ }^{2}$ which leaves us with some uncertainty regarding the specific station travelled to and/or from when analyzing sold tickets and passes.

A first step in a series of descriptive analyses consists of a two-sided Spearman correlation analysis. This will shed light on the direction and strength of the relations between the indicators belonging to different dimensions and fields, allowing for a validation of the conceptual model from a statistical point of view. As the proportion of missing values for the motivation and effort fields is fairly high, this correlation analysis is based on a list-wise deletion of missing values, resulting in a subset of 221 stations. Drawing on these descriptive statistics, a procedure to estimate the missing values in the remainder of the dataset can be set up, in order to develop a typology of stations inclusive of the effort and motivation fields. The procedure used is a multiple imputation (MI) algorithm and is conducted in SPSS. Since the values are missing in a non-random way, the monotone MI procedure is used. The "pooled" result (the average of the imputed values over 5 runs) is retained as a basis for the following analyses. The findings are detailed in section 3.1 .

Second, in order to verify to what extent the demand-side indicators add meaning to the findings of a conventional node-place type of classification, we conduct two cluster analyses. The first one only includes the supply-side accessibility fields (node, train and place), while the second one focuses on the demand-side fields. Both cluster analyses draw on an a priori exploratory factor analysis in order to generate a classification based on uncorrelated variables. The findings are detailed in section 3.2.

${ }^{2}$ There are 12 tariff zones in Flanders and Brussels: Aalst, Antwerp, Bruges, Brussels, Denderleeuw, Dendermonde, Ghent, Halle, Hasselt, Knokke, Leuven, Mechelen. 


\section{$3 \quad$ Findings}

\subsection{Correlation analysis}

When analyzing the direction and strength of correlations between the indicators (see Appendix 1), the following insights emerge.

First, the overall logic of the model seems justified: indicators belonging to the same field generally correlate strongly with each other and exhibit similar patterns with respect to the other fields. The decision to separate the train accessibility indicators from those of the feeder modes (bus, tram and metro) also seems justified, as correlations are clearly contained within both dimensions (e.g., the bus indicators have strong mutual correlations but exhibit weak correlations with the train indicators and vice versa). Furthermore, the assumed associations between the node and effort fields, the train and ridership fields, and the place and motivation fields seem supported by these findings. First, there is a clear positive relation between the distance people live from their station and the supply of car parking (and to a lesser extent bike parking) facilities and feeder public transport mode accessibility. Second, the ridership indicator is strongly positively correlated with most of the train indicators, especially with the frequency indicators. Third, the motivational factors, and in particular the secondary education profile, are generally significantly and strongly positively correlated with the place indicators. The ridership indicator "destination" is furthermore strongly positively correlated with all motivation indicators, justifying its location on the right-hand side of the ridership dimension in Figure 3.

On the indicator-level the following findings are noteworthy. The three design indicators are very strongly correlated (>.936). It thus seems that the extent of the public-private interface, the permeability of the street network and the total length of walking and cycling infrastructure to a large extent contain similar information about station area walkability. Further research could therefore look into alternative ways to assess walkable and bikeable access to stations mediated specifically by the built environment. The inclusion of measures of street network integration or connectivity as proposed by Pafka and Dovey (2018) may be a sensible addition here. The work by Nes and Stolk (2012) and Liu, Wu, Hidetosi, and Gao (2015) in which the spatial configuration of the local street network in railway precincts is assessed using Space Syntax analysis may prove instrumental. The open source "Urban Network Analysis" toolbox for ArcGIS (Sevtstuk \& Mekonnen, 2012) arguably also provides an interesting basis to refine centrality analyses of street networks with respect to railway stations (see, e.g., Sun, Zacharias, Ma, \& Oreskovic, 2016).

In a similar vein, the two diversity indicators are very strongly correlated, indicating that the intended differences in functional and spatial land-use diversity are not yet sufficiently captured. More experimentation with alternative Fragstats measures (and parameters) or alternative software packages is a sensible next step.

Furthermore, the two centrality indicators do not correlate strongly with other indicators, which suggests that both contain specific information about the network structure that is not covered by the other train indicators. Travel time centrality in particular does not exhibit any strong correlations, whilst transfer centrality is quite strongly correlated with the other train indicators.

A final reflection concerns the ridership indicator. Although it is beyond the scope of this paper to investigate the determinants of transit patronage in Flanders and Brussels (see, for example, Cardozo, García-Palomores, \& Guitiérrez, 2012; Chow, Zhao, Liu, \& Li, 2006), the correlation patterns do allow to explore some preliminary relations. Ridership is strongly correlated with (most indicators of) all other fields. Especially (free) car and bike parking supply, feeder public transport services, the design dimension, both educational motivations and the size of the catchment area are strongly related. Also, transfer centrality seems more important in explaining ridership than the travel time and frequencybased centrality measure. 


\subsection{Factor and cluster analysis}

In this section the results of two cluster analyses are discussed: a first one based on the supply-side accessibility characteristics (node, train, place) and a second one based on the demand-side accessibility characteristics (people). Clustering based on the full set of indicators did not result in an intelligible typology, hence the separate analyses discussed in two subsections.

\subsubsection{A typology for nodes and places}

The factor analysis (orthogonal, varimax rotation) results in 4 interpretable factors (see Appendix 2a) with an eigenvalue larger than 1 and explaining $81 \%$ of total variance. Factor 1 has strong loadings for nearly all place indicators, factor 2 for the train frequency indicators, factor 3 for most of the node indicators and the train amplitude and factor 4 for both centrality measures. Based on these factors, a Two Step cluster analysis (log-likelihood distance criterion and BIC clustering criterion) is conducted resulting in 5 interpretable groups of stations (see Figure 4). Brief descriptions for all station types are also provided in Figure 4.

The majority of stations in Flanders and Brussels classify as rural stations (very low scores on all place indicators) with weak bus and tram accessibility levels and weak railway accessibility in terms of frequency (on average 64 departing trains per Tuesday), but favorable in terms of network centrality. In other words, based on the actual NMBS timetables, these smaller stations with low public transport service frequencies are nonetheless located on the most important railway lines connecting the largest cities in Flanders, giving them robust and strategic potential in terms of future urban developments. Although most of these stations are located along the MTS spatial backbone sketched in Figure 1, the stations located both in the Western part and the Eastern part of Flanders exhibit a distinct typology. In these areas, types 2 and 4 are more abundant. Type 4 is characterized by very low bus and tram accessibility levels, and the lowest railway accessibility in terms of frequencies, amplitude and centrality; these stations are not at all or only weakly connected to the Walloon and foreign stations that are part of the network analysis. The level of "urbanity" of type 4 is nonetheless stronger than the type 1 stations which, from the perspective of a node-place equilibrium, arguably leads to a development scenario prioritizing higher railway accessibility in the network. The type 2 stations, in turn, are all located in urbanized areas

and - in contrast with the previous two types — exhibit sizable levels of bus and tram accessibility and have by far the highest car parking supply. Their railway-based accessibility is moderate, except for the service amplitude which is sizable in most cases. Geographically speaking this type is scattered, but there are nonetheless some clusters in and around the large cities of Kortrijk and Antwerp. The Brussels Capital Region is in turn predominantly characterized by stations of type 3. The main features of this type, differentiating it from the Flemish stations, are its very high scores on all place indicators and (mainly travel time) centrality measures. However, given the metropolitan context, the very low scores for the (mainly bike) parking facilities are striking. And finally, two of the three most important railway stations in the Belgian railway network (Brussels South and Brussels North) along with the main stations of the largest cities in Flanders, classify as type 5. The main distinctive factors are the very high frequencies and (mainly transfer) centrality scores and the very high bus, tram and metro accessibility levels.

\subsubsection{A user-based typology}

The factor analysis (orthogonal, varimax rotation) results in 4 factors (see Appendix 2b) with an eigenvalue of 1 and explaining 78\% of total variance. Factor 1 has strong positive loadings for destination, and the work and leisure motivations, while factor 2 strongly loads on the tertiary (and to a lesser extent 
secondary) education motivation and moderately loads on ridership. The third and fourth factor both cover the effort dimension, therefore only the third factor is retained. It loads strongly on large catchment areas where most people live further than a $3000 \mathrm{~m}$ radial buffer. The first three factors together explain $70 \%$ of total variance.

Based on these factors, a Two Step cluster analysis (log-likelihood distance criterion and BIC clustering criterion) is conducted resulting in 6 interpretable groups of stations (see Figure 5). The majority of stations in Flanders and Brussels classify as strong origin stations with semi large catchment areas (type 2). These stations are abundant across the region and are often located one after another along certain corridors in between the larger stations. The western and eastern parts of Flanders nonetheless mainly exhibit station types 1 and 3. The first type is quite similar to type 2 but is characterized by large catchment areas. Unsurprisingly, these stations are often located quite far from their neighboring stations, arguably explaining their larger catchments. Type 3 stations in turn have the largest catchment areas and are also characterized by strong leisure motivations (high destination motivations in terms of individual ticket sales). These are mainly destination stations and are located nearly exclusively in the periphery of the network, i.e. along and near the coastline in the West and at the end of some rail corridors in the East. The stations with the smallest catchment areas (type 5, strong origin stations) are in turn mainly located along some corridors in the center of the network. Finally, the station types with the least number of stations are types 4 and 6 . The type 4 stations are mixed origin/destination stations with a strong educational motivation and high to very high ridership. They are located at the cornerstones of the MTS sketched in Figure 1 and across the Brussels Capital Region. The strongest destination stations (type 6) are also mainly found in the urban regions of Brussels and Antwerp. The classifications of those stations located in the tariff zones should nonetheless be interpreted with prudence, as most of the people-based indicator scores (except for those part of the "ridership" field) are based on the imputation estimates described above.

\subsubsection{Blending typologies}

Table 5 illustrates by means of a cross-table how the stations are sorted across both typologies (NTP = Node, Train and Place, PP = People) and visualizes a rose diagram for each of the cluster intersections. The numbers indicate how much stations are included in the different intersections and the symbols across both sides pertain to those used in Figures 4 and 5. The dimensions in the diagrams are calculated as averages of the underlying indicators, and afterwards the dimension scores were rescaled to vary between 0 and 10 for each of the intersections.

Table 5 illustrates how the majority of railway stations in Flanders and Brussels classify within a limited number of cluster intersections. A clear example is the general overlap between the rural stations (type 1 in NTP) and the moderate to strong origin stations (1, 2 and 5 in PP). Likewise, the urban stations of type 2 in NTP are most often also moderate to strong origin stations with semi large to large catchments (types 1 and 2 in PP). A similar observation holds for the type 4 stations (NTP), while a distinct pattern is true for the metropolitan stations of type 3 in NTP, which classify predominantly as strong destination stations in the PP typology. The metropolitan stations of type 5 in NTP exclusively classify as the mixed origin/destination stations of type 4. These strong cluster intersections may not surprise given the earlier demonstrated correlations between the supply- and demand-side fields in the model. The confrontation of both typologies nonetheless allows for a more nuanced and differentiated account of a station's functioning in the Flemish and Brussels railway network when compared to a standard node-place typology, given that each NTP category diversifies into a range of distinct PP categories and vice versa. This comparative framework furthermore allows to identify stations that fit into unexpected or underrepresented "boxes" within Table 5, which can be submitted to further scrutinization. 
Table 5. Cross-table of cluster intersections with averaged rose diagrams
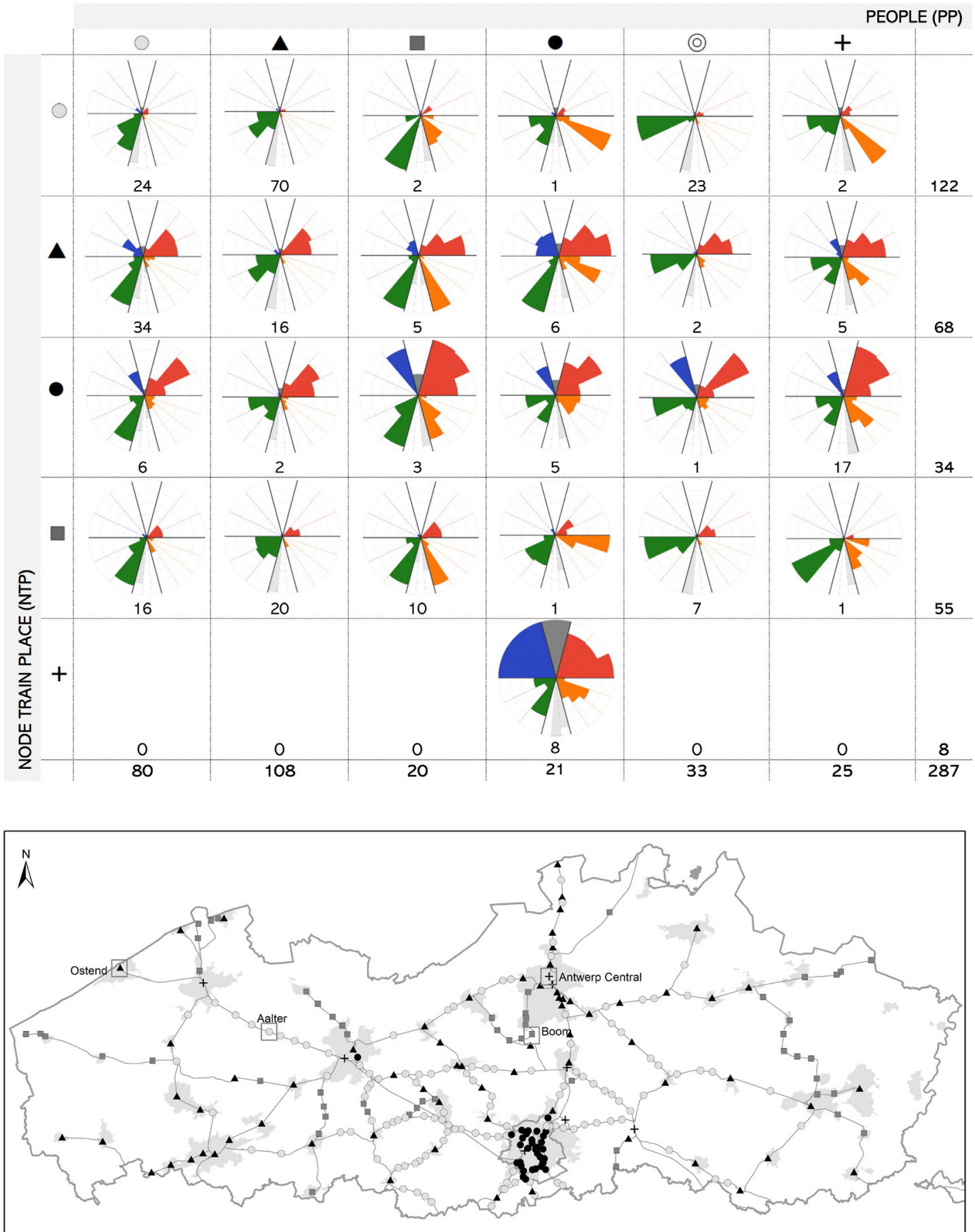

\section{Groups}

- 1 - rural with low frequency, average centrality, low parking supply and very low BTM accessibility

- 2 - urban with low frequency, average centrality, high parking supply and high BTM accessibility

- 3 - metropolitan with high frequency and centrality, very low parking supply and high BTM accessibility

- 4 - mix rural/urban with very low frequency and centrality, low parking supply and low BTM accessibility

+5 - metropolitan with very high frequency and centrality, very high parking supply and very high BTM accessibility railways

urban areas *

regional border

* Flemish Government (2016) and European Environment Agency (2006)

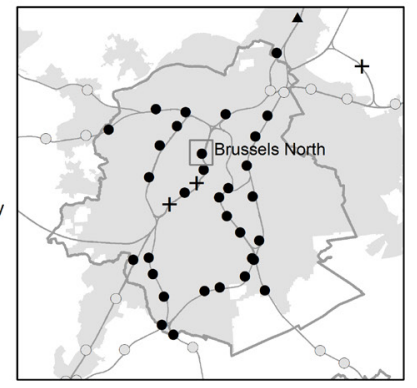

Figure 4. Typology of stations based on node, train and place dimensions 


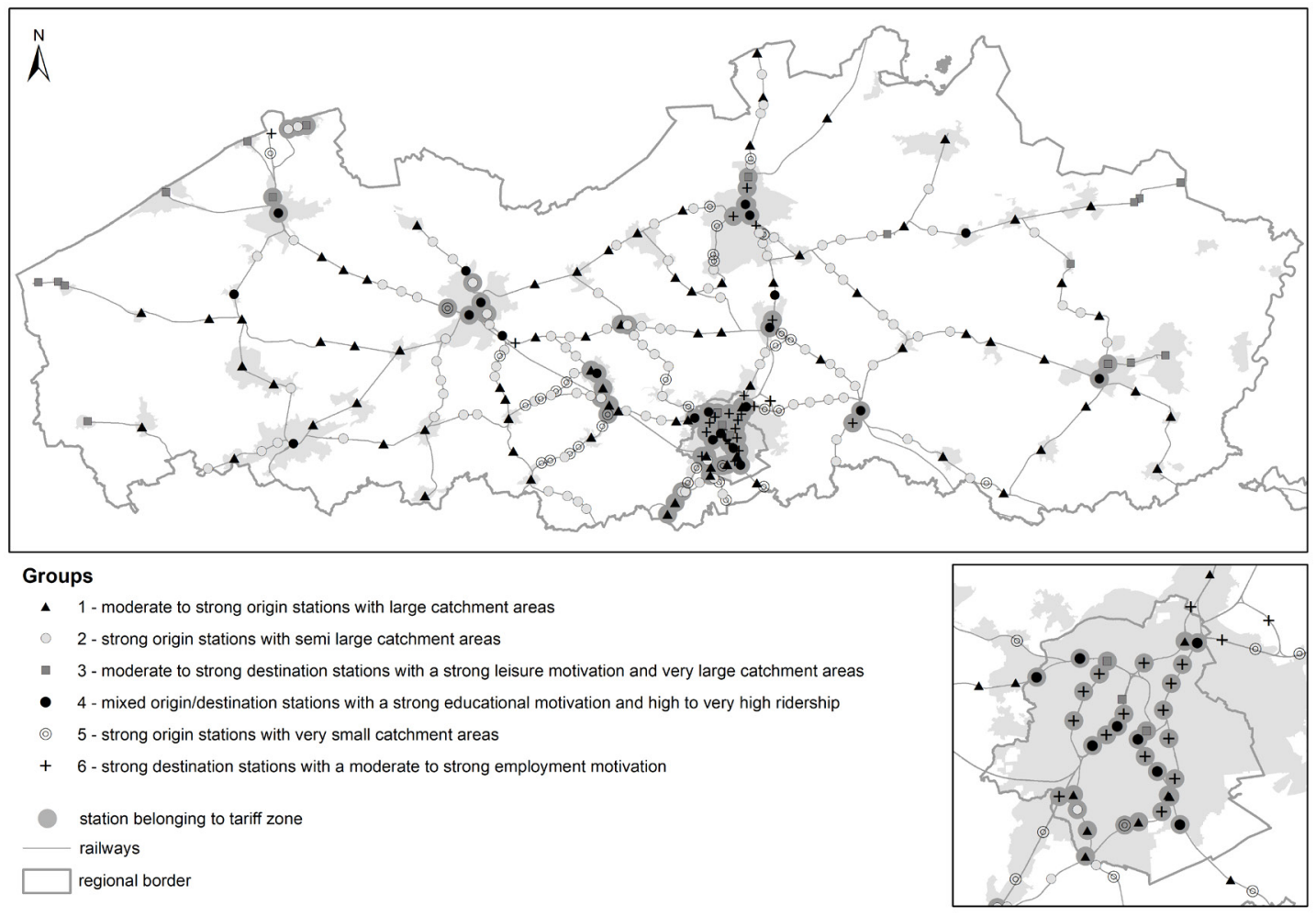

Figure 5. User-based typology of stations

\section{$4 \quad$ Practical application to five cases}

In order to clarify what the station-specific results of these analyses may mean for planning practice, this section discusses the characteristics of five railway stations. Each of these stations belongs to a cluster derived from the NTP typology (see Figure 4 where the five stations have been designated and Table 5 indicating their cluster membership for both typologies). We will also explain the position of the station at hand within the PP typology and relate our findings to the objectives of urban planning policies in Flanders and Brussels.

\subsection{Aalter station}

As indicated in Figure 4, Aalter station is located halfway between the larger cities of Bruges and Ghent. The strong growth of the municipality of Aalter since the 1970s, is a typical consequence of the suburbanization trend of that era, which was initially fueled by the smooth access of Aalter to the nearby motorway E40, but which is currently also complemented with reasonable access to the railway network. Judging from Figure 6, Aalter is a predominant origin station with a large catchment area where most people live farther than $3 \mathrm{~km}$ away from the station. The motivations to reach Aalter station as a destination station are very limited, with the exception of a small proportion of season tickets used for secondary education purposes. Although the number of daily passengers boarding (over 2,000) is quite sizable compared to the size of the municipality (more than 20,000 inhabitants), the ridership indicator scores very low when compared to all other stations in the network. Combined, these characteristics fit the station's classification as a type 1 station in the PP typology. 


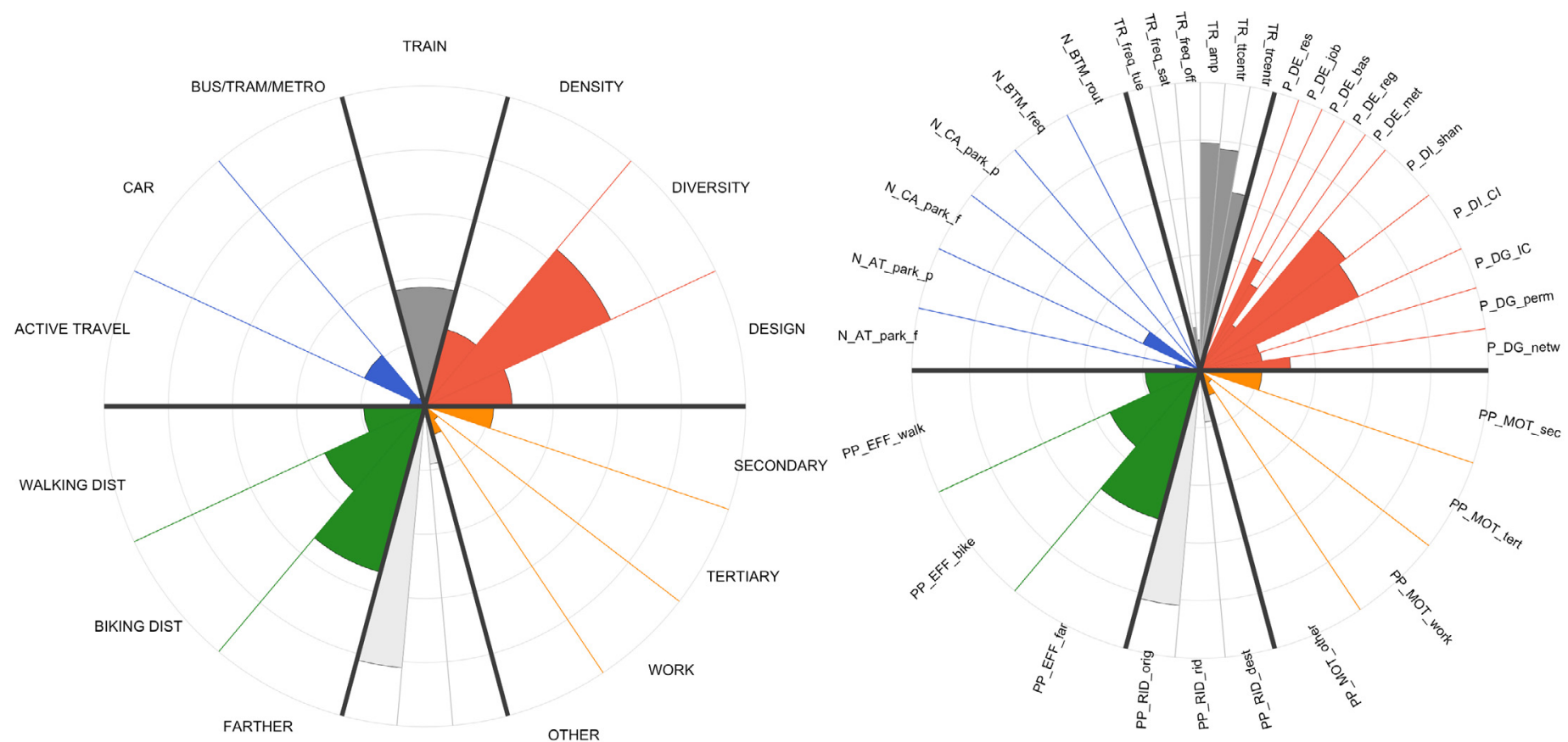

Figure 6. Aalter station scores (left: dimensions, right: indicators)

As most station users are living far from the station, from a sustainable mobility perspective one could expect a well-developed public transport service connecting the station with its hinterland. Judging from Figure 6, however, feeder public transport accessibility is very weak. There are two bus stops near the station serving two lines which together offer 41 bus departures on a working day. According to additional statistics, the modal share of public transport trips to and from the railway station is only 6\% (NMBS 2013). While the low density, suburban-style, catchment area of Aalter station-revealed by the place indicators in Figure 6-may hamper a more efficient development of feeder bus lines, this apparent mismatch may prove instrumental when discussing the potential for increased sustainable transport accessibility of the station. Due to its low-density walkable area (especially in terms of jobs and residents), Aalter station classifies as a rural station in the NTP typology (Figure 4). The station's walkable precinct nonetheless exhibits a notable functional and spatial diversity of the functions living, working and visiting. The station furthermore classifies as a station with low train frequencies, but with an average centrality in the network. The amplitude of the station is nonetheless favorable, along with its travel time (and to a lesser extent transfer) centrality. The latter observation may be explained by the bi-hourly direct service to Brussels (contrary to the neighboring local stations on the same railway line).

Policywise, Aalter is selected as an "economic node" but not as an "urban area," which limits development options. From a combination of contextual properties and results of the cluster analyses and Figure 6, we derive that the opportunities offered by this station can be valorized through densification of residential use in the immediate vicinity of the station and, at a later stage, such development could be supported by an increase in bus and train supply.

\subsection{Ostend Station}

Ostend station is the western terminus of the railway that used to be an important link on the international London-Brussels-Cologne route, until the opening of the Chunnel in 1994. Currently, the "regional urban area" of Ostend (over 71,000 inhabitants) no longer has a ferry connection, and the 
timetable of trains departing from this terminus is adapted to domestic traffic, which includes an important flow of long-distance commuters. According to the NTP typology, this station can be described as "urban with low frequency, average centrality, high parking supply and high BTM accessibility." This can be explained by, among other things, its location in a regional urban area, its status as a terminus, and its importance as a hub for regional public transport, the backbone of which is the coastal light railway. Although most train indicators score weak or moderate, the amplitude is very high.

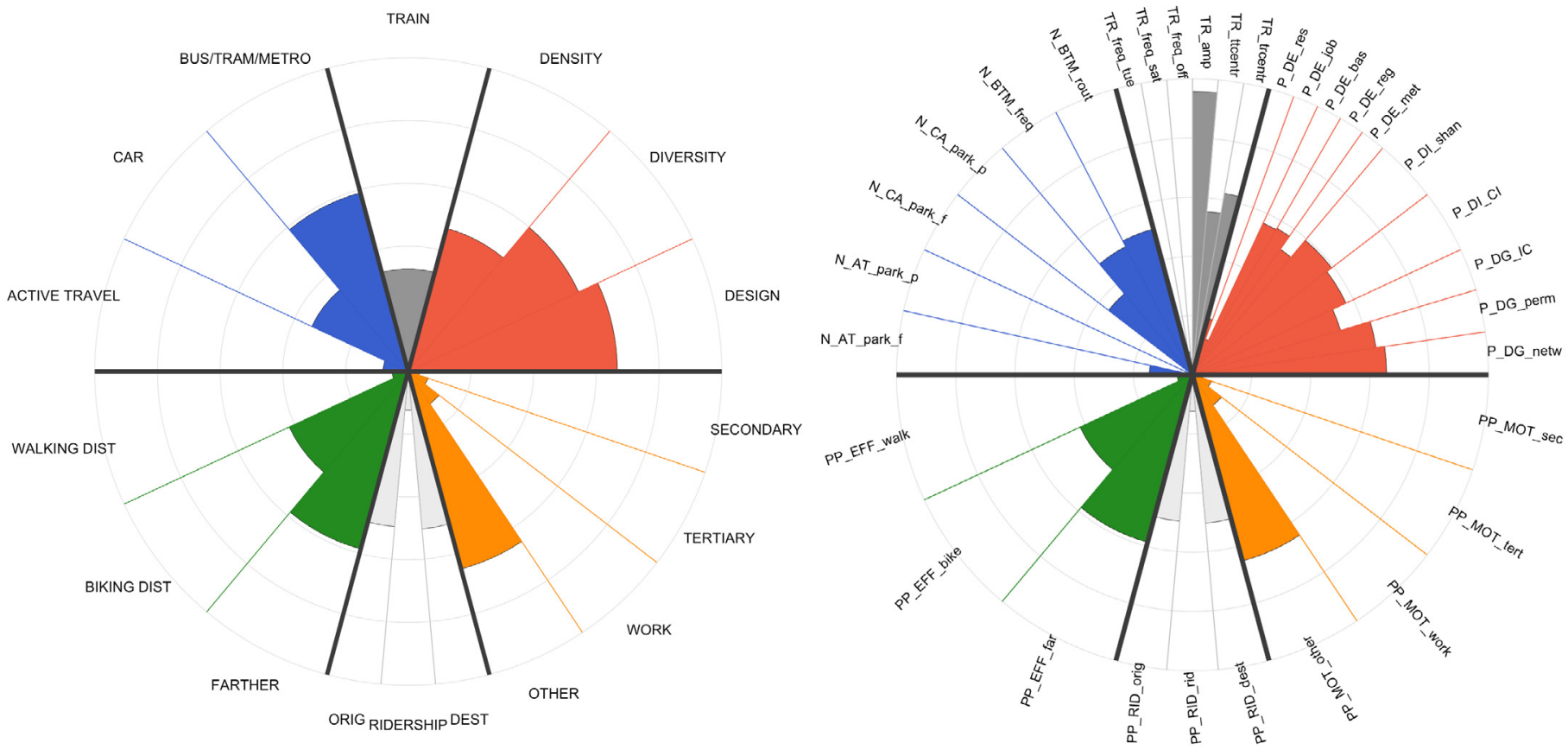

Figure 7. Ostend station scores (left: dimensions, right: indicators)

According to the PP typology, Ostend station is a "moderate to strong destination station with a strong leisure motivation and very large catchment area." This description seems to align with the accessibility profile provided in Figure 7, although the station in fact exhibits a "perfect" balance between an origin (long-distance commuters) and a destination (presence of the beach as a tourist attraction and sizable presence of regional and metropolitan amenities) character. The remote location of Ostend station in the national rail network may furthermore explain its large catchment area. The station's ridership on a Tuesday is about 7,600, which is significant but pales in comparison to the Brussels main stations (with over 61,000 boarding passengers).

Given the status of Ostend as a regional urban area, strengthening the current concentration of a mixed residential, professional, educational and recreational environment here would be an obvious policy option. The immediate vicinity of the station, which is located next to the currently underused seaport, is hardly developed and may well be suitable for compaction.

\subsection{Brussels North station}

Brussels North station is one of the three major stations of the Brussels north-south corridor, the busiest railway line in Belgium receiving around 1,200 trains per working day. The station is located centrally in the Brussels metropolitan area, which includes the Brussels Capital Region comprising 1.2 million inhabitants, and is situated between a modernist office district and a densely populated residential area. Judging from Figure 8, the train frequencies are maximal, both off-peak and in the weekend. Besides the 
amplitude indicator, all train indicators exhibit maximal scores. The place dimensions also score very high, except for the design indicators. Especially the network length of walk and bike paths receive mediocre scores in spite of the station being one of the most important railway hubs in the network. In a similar vein, the bike parking capacity of Brussels North is remarkably low and car parking at the station is also scarce. Furthermore, the station is an important hub in the Brussels tram and bus network, as well as in the Flemish regional public transport system, while virtually all trains serving the national airport call at this station. These characteristics align with the NTP type "metropolitan with high frequency and centrality, very low parking supply and high BTM accessibility."
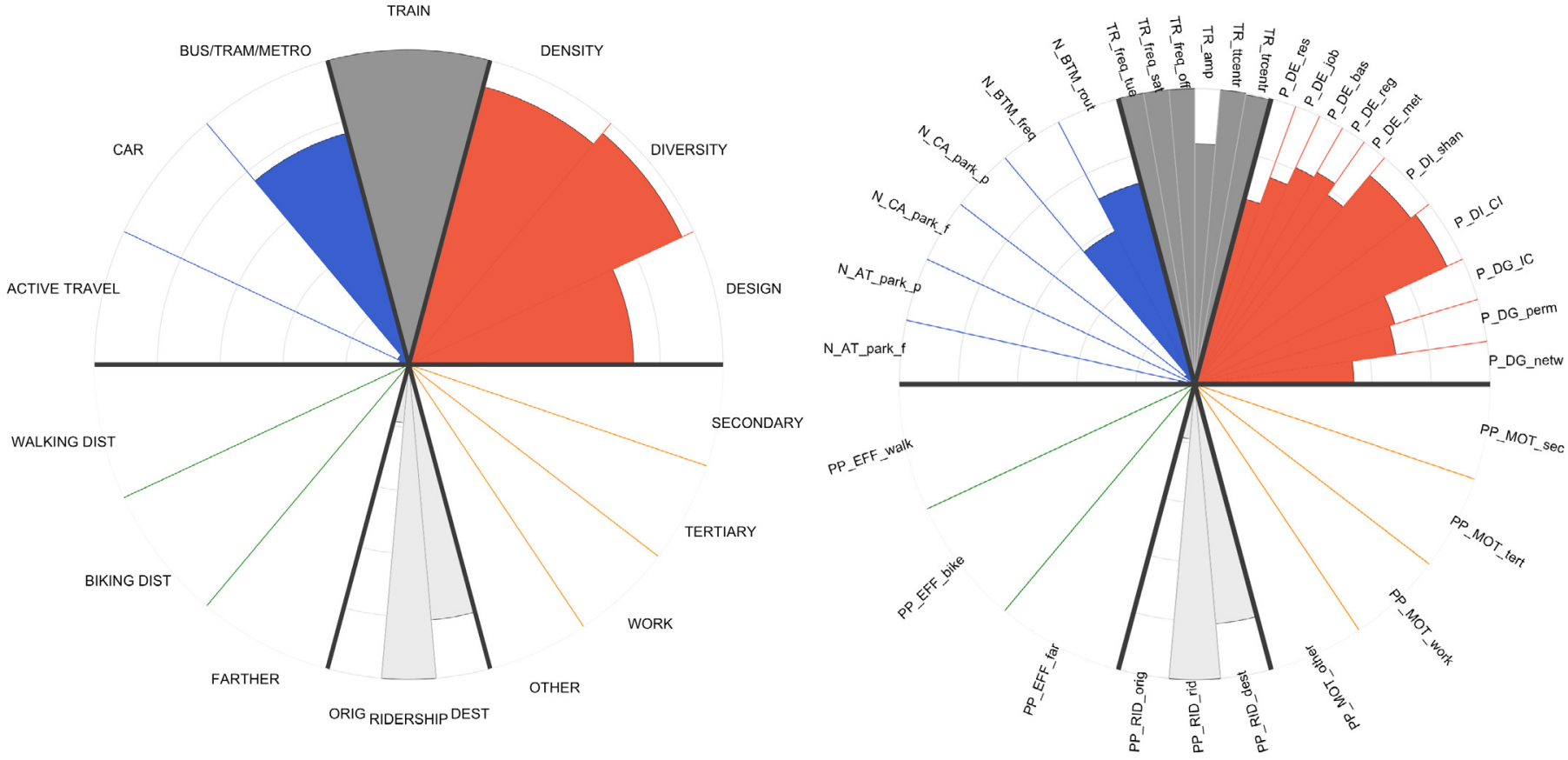

Figure 8. Brussels North station scores (left: dimensions, right: indicators)

From a user-based perspective, there is no information available for the effort and motivation dimensions as Brussels North is part of the Brussels tariff zone. From the other available NMBS data we can nonetheless derive that the station is a clear destination station and that it has a maximal ridership compared to the other stations in the network. It is the busiest station in the country on working days, with over 61,000 passengers boarding here.

Given the station's embedding in the metropolitan area and its pronounced role as a destination station (and transfer node), policy objectives could arguably focus on the further reinforcement of the functional mix of the wider station precinct through the development of additional housing.

\subsection{Boom station}

Boom station is located in the "small urban area" of Boom-Rumst (about 18,000 inhabitants). Judging from Figure 9, all node, train and place dimensions score moderate to low. The station classifies as "mix rural/urban with very low frequency and centrality, low-parking supply and low B/T/M accessibility." Despite the central location in the Flemish metropolitan core area, the station is poorly connected to the Belgian rail network, offering no significant connections to Brussels or other cities apart from Antwerp, which is especially reflected in a very low transfer centrality score, and a moderate travel time centrality score. Boom station is furthermore located next to a business park, in a location that is relatively isolated 
from the city center because of an expressway that locally cuts through the built environment and significantly decreases the size of the walkable station area (in turn affecting the design indicators).

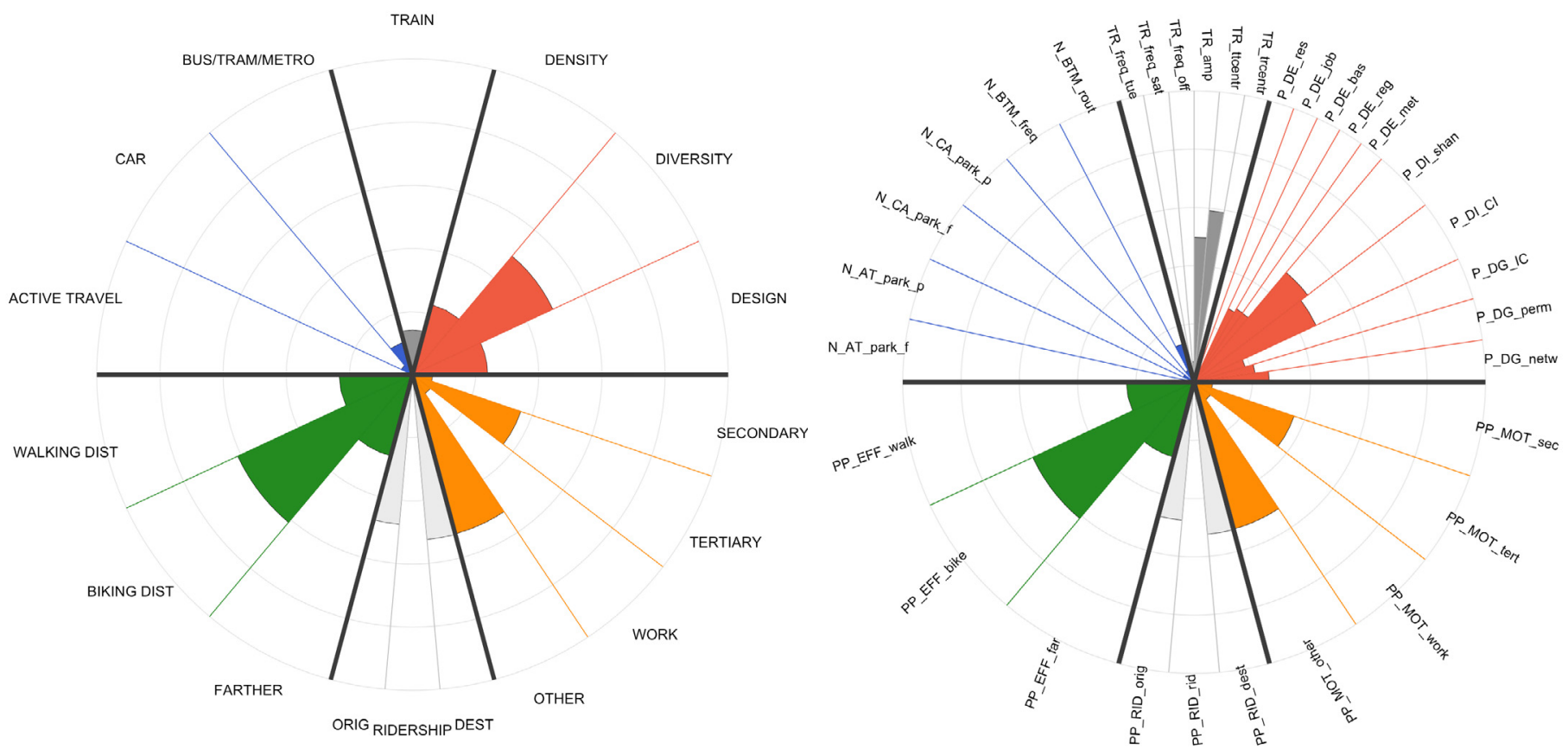

Figure 9. Boom station scores (left: dimensions, right: indicators)

According to the PP typology, Boom classifies as a "moderate to strong origin station with large catchment area." Figure 9 nonetheless reveals a mixed origin-destination profile and a semi-large catchment area. The motivations associated with its destination character are "other" (presumably leisure activities linked to the large nature recreational park nearby), and "tertiary education." The latter motivation is related to the presence of several post-secondary specialization grades offered by the Provincial Technical School, which is located close by the station. Finally, ridership is extremely low (about 230 people on a Tuesday).

Given its location in a "small urban area" in the Flemish metropolitan core area, and its current extremely low ridership, we derive that the potential offered by this station can only be realized if the quality of train supply would increase, its transfer centrality would improve, and if the station precinct would be made more attractive. Compaction objectives appear therefore less urgent.

\subsection{Antwerp Central Station}

Antwerp Central station is embedded in the "metropolitan area" of Antwerp, which includes the city of Antwerp (over 520,000 inhabitants). The station belongs to the cluster "metropolitan with very high frequency and centrality, very high parking supply and very high BTM accessibility." The station has recently been part of a large-scale urban renewal project, which included the expansion of the station into a hub of high-speed rail traffic towards the Netherlands (reflected in its high scores on the centrality indicators). The station is very centrally located in the urban fabric and is embedded in a strongly mixed and high-density residential area (reflected by the place indicators). The recent developments have added an office district and a large parking garage to the project (reflected by the notable score on the paying car parking supply), and the station also functions as a hub of urban public transport (tram, premetro and bus) (reflected by the high B/T/M scores). 
From a user-based perspective, there is no information available for the effort and motivation dimensions (Antwerp Central station is part of the Antwerp tariff zone). We can nonetheless derive that the station is predominantly a destination and that it has a high ridership (35,000 passengers boarding on weekdays, making it the fifth busiest station of Belgium). Moreover, the station building is an architectural showpiece and a tourist attraction, which was in 2014 named "the most beautiful station in the world" by the British-American news site Mashable.

The large capacity that the station has acquired since the renovation in 2007 allows for a gradual growth of activities and residences in the station precinct, in the longer term to be combined with a rise in the supply of train services.
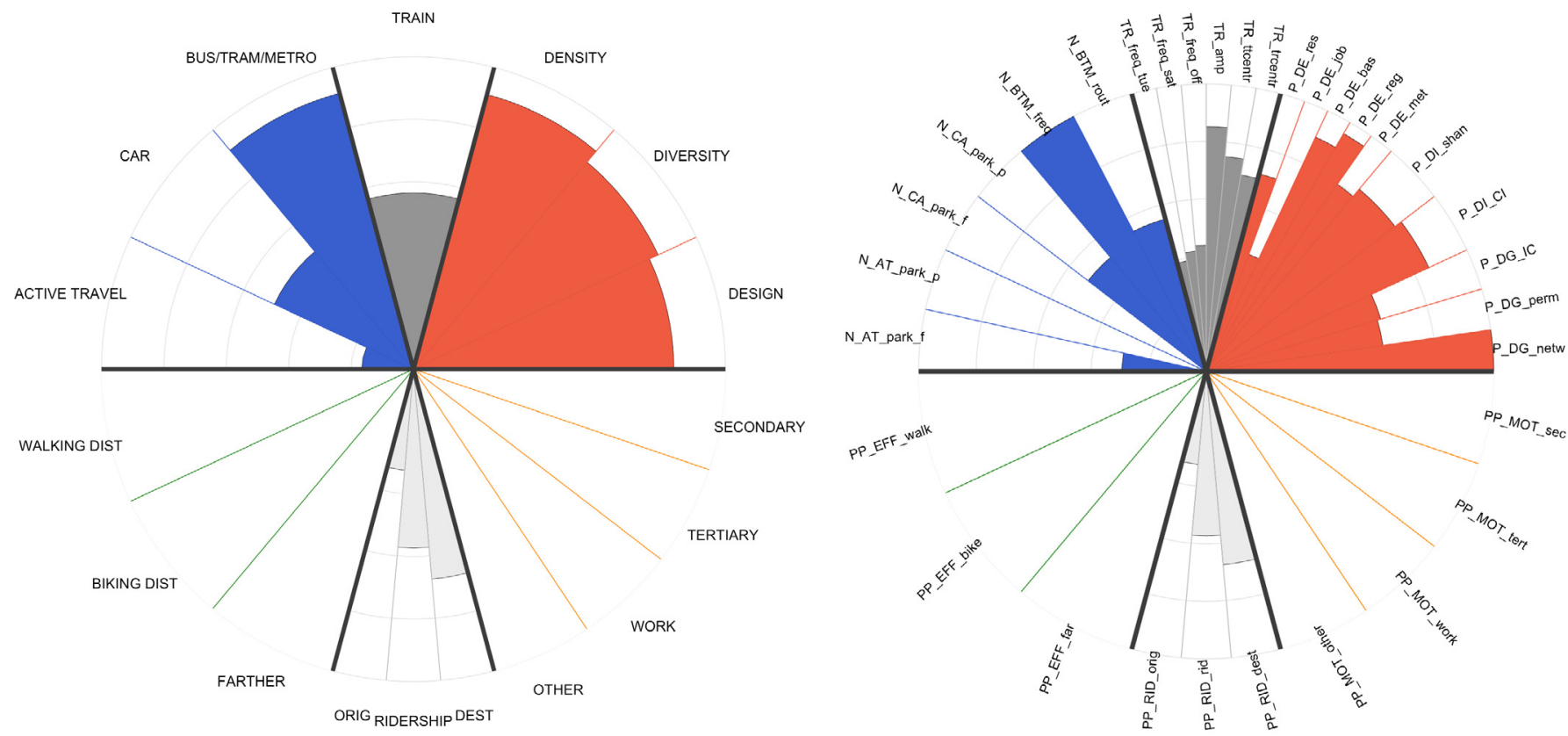

Figure 10. Antwerp Central Station scores (left: dimensions, right: indicators)

\section{$5 \quad$ Conclusions}

This paper had two related objectives. First, we aimed to methodologically contribute to the literature on empirical station assessment models drawing on node-place modeling principles. We suggested and implemented strategies to improve the analytical strength of some standard node and place measures, took some precursory steps to broaden the model with temporal variability in accessibility and, most notably, complemented the standard supply-side accessibility information with a demand-side perspective focusing on the station users. These differentiated accessibility perspectives were structured along several fields and dimensions of a rose diagram, in line with their hypothesized (and statistically validated) reciprocal relations. In this way, station accessibility profiles are generated summarizing a variety of empirically collected information for all railway stations in the Flemish and Brussels railway network. Based on a discussion of some concrete examples, we illustrated how these rose diagrams produce insight and reveal detailed knowledge about station-specific accessibility dynamics, some of which are not captured in standard node-place analyses.

Second, we interpreted the findings of the empirical analyses of Flanders and Brussels in the broad spirit of the recently approved BRV strategic vision (Flemish Government, 2018). To this end, we used our empirical findings to produce two groupings of stations, the first one based on a standard node-place analysis and a second one drawing on the user-based data acquired from NMBS. We demonstrated and 
discussed how both typologies intersect geographically, and how they may each provide unique information about the functioning of stations within the Flemish and Brussels railway network. By doing so, our research serves as a refinement of the conceptual typology of strategic railway stations put forward in the BRV strategic vision and the "spatial backbone" operational framework. Additionally, our analysis is comprehensive in that it includes all railway stations in both regions, allowing to deduce meaningful observations for those stations that fall outside the scope of the BRV typology (which strictly focuses on the stations situated along the MTS).

We nonetheless point out that the rose diagrams developed in this paper may lose their informative capacity when used in isolation from cartographic material and/or when absolute figures underpin the relative scores in the diagrams. As this station assessment model is intended to help developing a "useful" and "usable" (see Pelzer, 2017) planning support system (PSS), we presume that additional maps that serve to clarify and increase the interpretation of specific indicator scores, as well as additional tables detailing the absolute figures behind the relative scores will be crucial. After all, several studies dealing with interdisciplinary communication processes facilitated by PSS (see Geertman \& Stillwell, 2009; Pelzer \& Geertman, 2014; Papa, Coppola, Angiello, \& Carpentieri, 2017) stress the importance of spatial visualizations and of transparency in data and methods to render results more easily understandable and relevant for the end users of the tool. In these earlier studies, the added value of node-place analyses as perceived by their intended end users is nonetheless rarely evaluated; to the best of our knowledge, there are no such studies with the exception of Gilliard et al. (2018), that critically validated a node-place model application in a design studio setting with urban design students. This observation has a broader significance, as few planning support instruments commonly discussed in the literature are explicitly validated by their intended users (te Brömmelstroet, 2010; Straatemeier, Bertolini, te Broömmelstroet, \& Hoetjes, 2010; Pelzer, Geertman, vander Heijden, \& Rouwette, 2014; see also Bertolini, 2017). This lack of cross-fertilization between the output of applied academic research and actual planning instruments hampers the integration of scientific and practical knowledge (Balducci \& Bertolini, 2007).

In order to help bridge the gap between planning research and planning practice, a next step in this research will therefore consist of a qualitative validation of the usefulness of this model in the Flemish context. Given the growing importance of the urban-regional governance level in integrating transport and land use in Flanders, a sensible strategy would be to focus on the recently (2018) established "transport regions." The objective of these new regional partnerships (15 in total) is to stimulate cooperation between municipalities, public transport operators, the Flemish Government and other stakeholders around the organization and coordination of public transport in the region, and this in close cooperation with spatial interventions. A validation of the model in this context should inform us about the extent to which particular building blocks of the model require modification to better fit the needs of its end users. It might turn out that our concern with the pursuit of rigor (or "soundness," see Bertolini, Clercq, \& Kapoen, 2005) in the operationalization of certain indicators, proves less directional for the future development of our planning support tool. In this way, the frequently raised contention that PSS developers should seek for an effective balance between scientific rigor and practical relevance (see among others, Papa, Silva, te Brömmelstroet, \& Hull, 2016; Silva \& Larsson 2018) may be put to the test.

\section{Acknowledgements}

The authors would like to thank both NMBS and VITO (Vlaamse Instelling voor Technologisch Onderzoek) for their provision of data in the context of this research. The research reported in this article is supported by FWO (Fonds Wetenschappelijk Onderzoek, file number 1S09616N). 


\section{References}

Balducci, A., \& Bertolini, L. (2007). Reflecting on practice or reflecting with practice? Planning Theory \& Practice, 8(4), 532-555.

Bertolini, L., \& Spit, T. (1998). Cities on0 rails: The redevelopment of railway stations and their surroundings. London: Routledge.

Bertolini, L. (1999). Spatial development patterns and public transport: The application of an analytical model in the Netherlands. Planning Practice and Research, 14(2), 199-210.

Bertolini, L., Clercq, F., \& Kapoen, L. (2005). Sustainable accessibility: A conceptual framework to integrate transport and land use plan-making. Two test-applications in the Netherlands and a reflection on the way forward. Transport Policy, 12(3), 207-220.

Bertolini, L. (2017). Planning the mobile metropolis. Transport for people, places and the planet. London: Palgrave and Macmillan Education.

Blondia, M. (2014). Een geïntegreerd regionaal openbaar vervoersproject voor de Nevelstad \& strategieën voor de transformatie van het Vlaams openbaar vervoersnetwerk. Doctoral dissertation, Leuven University, Belgium.

Blondia, M., \& De Deyn, E. (2012). Regional LRT as a backbone for the peri-urban landscape: Research by design on an intermodal public transport network. Paper presented at the 2012 AESOP Conference, Ankara, Turkey.

Boussauw, K., \& Boelens, L. (2015). Fuzzy tales for hard blueprints: The selective coproduction of the Spatial Policy Plan for Flanders, Belgium. Environment and Planning C: Politics and Space, 33, 1376-1393.

Boussauw, K., van Meeteren, M., Sansen, J., Meijers, E., Storme, T., Louw, E., ... Witlox, F. (2018). Planning for agglomeration economies in a polycentric region: Envisioning an efficient metropolitan core area in Flanders. European Journal of Spatial Development, 69, 1-26.

Cardozo, O. D., García-Palomares, J. C., \& Gutiérrez, J. (2012). Application of geographically weighted regression to the direct forecasting of transit ridership at station-level. Applied Geography, 34, 548-558.

Caset, F., Vale, S. D., \& Viana, C. M. (2018). Measuring the accessibility of railway stations in the Brussels Regional Express Network: A node-place modeling approach. Networks and Spatial Economics. doi.10.1007/s11067-018-9409-y

Cervero R., \& Kockelman, K. (1997). Travel demand and the 3Ds: Density, diversity, and design. Transportation Research Part D: Transport and Environment, 2(3), 199-219.

Chorus, P., \& Bertolini, L. (2011). An application of the node-place model to explore the spatial development dynamics of station areas in Tokyo. Journal of Transport and Land Use, 4(1), 45-58.

Chow, L.-F., Zhao, F., Liu, X., \& Li, M.-T. (2006). Transit ridership model based on geographically weighted regression. Transportation Research Record, 1972(1), 105-114.

Curtis, C., \& Scheurer, J. (2010). Planning for sustainable accessibility: Developing tools to aid discussion and decision-making. Progress in Planning, 74(2), 53-106.

Curtis, C., \& Scheurer, J. (2016). Planning for sustainable accessibility: An international sourcebook. London: Routledge.

De Vos, J. \& Witlox, F. (2013). Transportation policy as spatial planning tool: Reducing urban sprawl by increasing travel costs and clustering infrastructure and public transportation. Journal of Transport Geography, 33, 117-125.

Dovey, K., \& Pafka, E. (2018a). Densities. In K. Dovey, A. Pafka, \& M. Ristic (Eds.), Mapping urbanities: Morphology, flows, possibilities (pp. 62-81). London: Routledge. 
Dovey, K., \& Pafka, E. (2018b). Functional mix. In K. Dovey, A. Pafka, \& M. Ristic (Eds.), Mapping urbanities: Morphology, flows, possibilities (pp. 19-40). London: Routledge.

Flemish Government. (2017). Working together on the space of tomorrow. Brochure to the White Paper on the Spatial Policy Plan for Flanders. Retrieved from https://www.ruimtevlaanderen.be/ Portals/108/WhitePaperSpatialPolicyPlanFlanders_brochure2017_1.pdf

Flemish Government. (2018). Beleidsplan Ruimte Vlaanderen: Strategische Visie. Retrieved from https://www.ruimtevlaanderen.be/Portals/108/BRV_StrategischeVisie_VR20181307DOC.pdf

Fransen, K., Neutens, T., Farber, S., De Maeyer, P., Deruyter, G., Witlox, F. (2015). Identifying public transport gaps using time-dependent accessibility levels. Journal of Transport Geography 48, 176-187.

Geertman, S., \& Stillwell, J. (Eds.) (2009). Planning support systems: Best practices and new methods. Heidelberg: Springer.

Geurs, K. T. (2006). Accessibility, land use and transport. Delft, NL: Eburon Academic Publishers.

Giannopoulos, G. A., \& Boulougaris, G. A. (1989). Definition of accessibility for railway stations and its impact on railway passenger demand. Transportation Planning and Technology, 13(2), 111-120.

Gilliard, L., Wenner, F., Belahuski, G. B., Nagl, E., Rodewald, A., Schmid, F, ... Thierstein, A. (2018). Using boundary objects to make students brokers across disciplines: A dialogue between students and their lecturers on Bertolini's node-place model. Transactions of the Association of European Schools of Planning, 2, 81-98. doi.10. 24306/ TrAESOP. 2018.01.006

Groenendijk, L., Rezaei, J., \& Homem de Almeida Correia, G. (2018). Incorporating the travelers' experience value in assessing the quality of transit nodes: A Rotterdam case study. Case Studies on Transport Policy, 6(4), 564-576.

Hess, P., Moudon, A. V., \& Logsdon, M. (2001). Measuring land-use patterns for transportation research. Transportation Research Record, 2512, 17-24.

Liu, J., Wu, D., Hidetosi, F., \& Gao, W. (2015). Investigation and analysis of urban spatial structure around the train stations in Kitakyushu by using Space Syntax and GIS. Open Journal of Civil Engineering, 5, 97-108.

Marshall, S. (2005). Streets and patterns. London: Spon Press.

McGarigal, K., \& Marks, B. J. (1995). FRAGSTATS: Spatial pattern analysis program for quantifying landscape structure. (Technical Report PNW-GTR-351). Portland, OR: U.S. Department of Agriculture, Forest Service, Pacific Northwest Research Station.

Nes, A., Berghauser P. M., \& Mashhoodi, B. (2012). Combination of space syntax with spacematrix and the mixed use index. Paper presented at the 8th International Space Syntax Symposium, Santiago de Chile.

Nes, A., \& Stolk, E. (2012). Degrees of sustainable location of railway stations: Integrating space syntax and node place value model on railway stations in the province of North Holland's strategic plan for 20102040. Paper presented at the 8th International Space Syntax Symposium, Santiago de Chile.

Newman, M. E. J. (2010). Networks: An introduction. Oxford, UK: Oxford University Press.

NMBS. (2013). Modal split van de klanten in de Belgische stations: Resultaten \& duiding. (Technical Report B-Mobility Holding). Brussels: NMBS Holding.

Pafka, E., \& Dovey, K. (2018). Walkable access. In K. Dovey, A. Pafka, \& M. Ristic (Eds.), Mapping urbanities: Morphology, flows, possibilities (pp. 41-61). London: Routledge.

Papa, E., Moccia, F. D., Angiello, G., \& Inglese, P. (2013). An accessibility planning tool for network transit oriented development: SNAP. Planum, The Journal of Urbanism, 27(2), 1-9.

Papa, E., Coppola, P., Angiello, G., \& Carpentieri, G. (2017). The learning process of accessibility instrument developers: Testing the tools in planning practice. Transportation Research Part A, 104, $108-120$. 
Papa, E., Silva, C., te Brömmelstroet, M., \& Hull, A. (2016). Accessibility instruments for planning practice: A review of European experiences. Journal of Transport and Land Use, 9(3), 57-75.

Peek, G. J. (2006). Locatiesynergie: Een participatieve start van de herontwikkeling van binnenstedelijke stationslocaties. Delft, NL: Eburon Academic Press.

Pelzer, P., \& Geertman, S. (2014). Planning support systems and interdisciplinary learning. Planning Theory \& Practice, 15(4), 527-542.

Pelzer, P., Geertman, S., van der Heijden, R., \& Rouwette, E. (2014) The added value of planning support systems: A practitioner's perspective. Computers, Environment and Urban Systems, 48, 16-27.

Pelzer, P. (2017). Usefulness of planning support systems: A conceptual framework and an empirical illustration. Transportation Research Part A, 104, 84-95.

Province of North Holland and Deltametropolis Association. (2013). Maak plaats! Werken aan knooppuntontwikkeling in Noord-Holland. Haarlem, NL: Province of North Holland and Deltametropolis Assocation.

Ryan, S., \& Frank, L. F. (2009). Pedestrian environments and transit ridership. Journal of Public Transportation, 12(1), 39-57.

Sevtsuk, A., \& Mekonnen, M. (2012). Urban network analysis toolbox. International Journal of Geomatics and Spatial Analysis, 22(2), 287-305.

Silva, C., \& Larsson, A. (2018). Challenges for accessibility planning and research in the context of sustainable mobility: Discussion paper. Paper presented at the International Transport Forum, Paris.

Singh, Y. J., Fard, P., Zuidgeest, M., Brussel, M., \& van Maarseveen, M. (2014). Measuring transitoriented development: A spatial multi criteria assessment approach for the City Region Arnhem and Nijmegen. Journal of Transport Geography, 35, 130-143.

Singh, Y. J., Lukman, A., Flacke, J., Zuidgeest, M., \& van Maarseveen, M. F. A. M. (2017). Measuring TOD around transit nodes-Towards TOD policy. Transport Policy, 56, 96-111.

Stadsregio Arnhem Nijmegen (2011). Knooppunten! Bereikbaarheid en ruimtelijke ontwikkeling op knooppunten van openbaar vervoer. Arnhem: Stadsregio Arnhem-Nijmegen.

Straatemeier, T., Bertolini, L., te Brömmelstroet, M., \& Hoetjes, P. (2010). An experiential approach to research in planning. Environment and Planning Part B, 37, 578-591.

Sun, G., Zacharias, J., Ma, B., \& Oreskovic, N. M. (2016). How do metro stations integrate with walking environments? Results from walking access within three types of built environment in Beijing. Cities, 56, 91-98.

te Brömmelstroet, M. (2010). Making planning support systems matter: Improving the use of planning support systems for integrated land use and transport strategy-making. $\mathrm{PhD}$ dissertation, University of Amsterdam, the Netherlands.

Vale, D., Saraiva, M., \& Pereira, M. (2016). Active accessibility: A review of operational measures of walking and cycling accessibility. Journal of Transport and Land Use, 9(1), 209-235.

Vale, D. S., Viana, C. M., \& Pereira, M. (2018) The extended node-place model at the local scale: Evaluating the integration of land use and transport for Lisbon's subway network. Journal of Transport Geography, 69, 282-293.

van den Hoek, J. (2008). The MXI (mixed-use index) as a tool for urban planning and analysis. Corporations and Cities (pp. 1-5). Delft, NL: Delft University of Technology.

van Meeteren, M., Boussauw, K., Sansen, J., Storme, T., Louw, E., Meijers, E., ... Witlox, F. (2015) Kritische massa: Verdiepingsrapport. (Research Report). Brussels: Ruimte Vlaanderen.

Verachtert, E., Mayeres, I., Poelmans, L., van der Meulen, M., Vanhulsel, M., \& Engelen, G. (2016). Ontwikkelingskansen op basis van knooppuntwaarde en nabijheid voorzieningen. Eindrapport. (Technical Report VITO 2016/RMA/0545). Mol, Belgium: VITO, Vlaamse Instelling voor 
Technologisch Onderzoek.

Zweedijk, A., \& Serlie, Z. (1998). Een "knoop-plaats"-model voor stationslocaties. Geografie, 7(5), 35-37.

\section{Appendices}

Appendices are available as supplemental files at https://www.jtlu.org/index.php/jtlu/article/view/1483 